\title{
Emanuel Kulczycki
}

\section{Punktoza \\ jako strategia w grze parametrycznej \\ w Polsce}

STRESZCZENIE. W artykule stosuję pojęcie „gry parametrycznej”, aby opisać strategię pracy akademickiej pojawiającej się w Polsce jako efekt wprowadzenia polityk punktowego nagradzania dorobku naukowego. „Gra parametryczna” oznacza realizowanie badań i publikowanie ich wyników w taki sposób, aby spełniać wymagania danego systemu ewaluacji nauki. W grze tej badacze mogą używać dwóch strategii. Pierwszą jest „impactitis”, w ramach której tylko publikacje w czasopismach z wysokim Impact Factorem są uznawane w danej społeczności akademickiej. Drugą strategią jest „punktoza”. Polega ona na tym, że bardziej opłacalne jest opublikowanie kilku artykułów w czasopiśmie bez Impact Factora niż opublikowanie jednego artykułu w wysoko punktowanym czasopiśmie. Na podstawie polskiego systemu ewaluacji nauki (parametryzacji) pokazuję główne mechanizmy wytwarzania punktozy oraz takie, które mają ograniczać negatywne konsekwencje grania w parametryczną grę. Tekst kończy się dyskusją na temat rozwiązań polskiego systemu oraz rekomendacjami, jak system ten można ulepszyć i jakie lekcje należy wyciągnąć z obecnej sytuacji. Przedstawione konkluzje są istotne zarówno dla badaczy, jak i decydentów z obszaru polityki naukowej z innych krajów.

SŁOWA KLUCZOWE: gra parametryczna, punktoza impactictis, Polska, ewaluacja nauki

\section{Wstęp}

Pracownicy naukowi w drugiej dekadzie XXI wieku uczestniczą w transformacjach, które stoją pod znakiem globalizacji (Kwiek 2014), nowych modeli zarządzania kładących nacisk na policzalność i rozliczalność efektów (Szadkowski 2015), tworzących w efekcie tzw. przyśpieszoną akademię, opierającą się na różnych rankingach i postulatach rozliczalności. Obecnie główną zasadę organizacji i zarządzania nauką oraz szkolnictwem wyższym można scharakteryzować następująco: wszystko ma być możliwe do zmierzenia i oceniania, a na tej podstawie mają być podejmo- 
wane skuteczne i - na ile to możliwe - zobiektywizowane decyzje dotyczące organizacji i finansowania nauki. Na zarządzanie nauką duży wpływ ma również przyjęcie indywidualnie i instytucjonalnie rozumianej produktywności naukowej jako podstawowej miary rozliczalności oraz - mocno z tym związany - rozwój rynku wydawniczego.

Podstawową miarą produktywności naukowej stały się różne czynniki związane z pracownikami naukowymi oraz publikacjami. Benoît Godin (2009) wyróżnia cztery etapy zmian w rozumieniu i wykorzystywaniu produktywności naukowej. W pierwszym etapie za sprawą Francisa Galtona i Jamesa McKeena Cattella na przełomie XIX i XX wieku miarą produktywności w nauce była reprodukcja „ludzi nauki” (men of science), czyli dążenie do tego, by w nauce było coraz więcej dobrych naukowców. Drugi etap związany był z zastosowaniem metod statystycznych do analizy publikacji naukowych - w ten sposób produktywność została ujęta w ramy wytwarzania dobrych publikacji, które rozwijają naukę. Trzeci etap - w latach 40. i 50. XX wieku - nie był już skoncentrowany na ludziach nauki i ich produktywności, lecz na relacji nakładów w naukę i zwrotów z tych nakładów, czyli na wydajności zainwestowanych pieniędzy. Ostatni etap, w który wkroczyliśmy w drugiej połowie XX wieku, nie koncentruje się już tylko na liczbie i wydajności publikacji naukowych, ale przede wszystkim na wpływie nauki na produktywność ekonomiczną - nauka jest zatem rozumiana jako praktyka służąca głównie zwiększaniu wzrostu gospodarczego.

Obecnie aktywność pojedynczego naukowca jest oceniana za pomocą wskaźników bibliometrycznych mających być pośrednią miarą wpływu naukowca i jego prac (np. indeks Hirscha, sumaryczny Impact Factor, alternatywne metryki). Czasopisma oceniane są na podstawie cytowalności (Impact Factor, SNIP, SJR), a jednostki naukowe ewaluowane w ramach różnych krajowych systemów oceny nauki (system ekspercki, system parametryczny) (Hicks 2012). We wszystkich tych podejściach do mierzenia produktywności naukowców poprzez ich publikacje ścierają się ze sobą dwie perspektywy: 1) ilościowa - oparta na wielowymiarowych wskaźnikach i parametrach; 2) jakościowa - oparta na ocenie równych przez równych (ang. peer review) lub ocenie eksperckiej (ang. expert-based assessment). Obie te perspektywy są wykorzystywane zarówno do zaspokajania ciekawości poznawczej, jak i pomiaru efektywności w kontekście zwrotu z inwestycji publicznych, poprzez ogólną ewaluację i mierzenie różnorodnego wpływu nauki na gospodarkę.

Kolejnym czynnikiem wpływającym na sposób zarządzania obszarem nauki i szkolnictwa wyższego jest rozwój rynku wydawniczego. Towarzyszy mu wyłonienie oligopoli kontrolujących niemalże cały rynek naukowy (Larivière i in. 2015), pojawienie się nowych modeli upowszechniania i promocji nauki opartych na otwartym dostępie do publikacji (Kulczycki 2016) oraz nowych kanałów i gatunków publikacji naukowych, takich jak nanopublikacje, media społecznościowe dla naukowców czy wideoczasopisma i abstrakty. 
Rozliczalność, rozwój rynku wydawniczego, dostępność narzędzi internetowych oraz potrzeba zwiększania wartości wskaźników bibliometrycznych przez naukowców sprawiły, że w praktykach naukowych pojawiły się działania, które można uznać za przestępcze, np. fałszowanie wyników badań lub postępowania łamiące zasady etycznego prowadzenia badań i publikowania ich wyników, np. wykorzystywanie tych samych wyników do tworzenia wielu publikacji (określane niekiedy potocznie „mieleniem kotleta”, ang. duplicate publications), nieuzasadnione dzielenie ważnych wyników na jak największą liczbę publikowalnych artykułów („krojenie salami”, ang. salami slicing), nieuczciwości we wskazywaniu autorstwa publikacji naukowych poprzez niewskazywanie rzeczywistych autorów (,autorzy-widma", ang. ghost authors) lub dodawanie osób, które nie przyczyniły się do powstania tekstu (,autorstwo honorowe”, ang. honorary authorship). Przyczyn tych praktyk upatruje się m.in. w „przyśpieszeniu” całego świata akademickiego (Szadkowski 2016; Vostal 2016), który nastawiony jest na jak najszybszą publikację wyników naukowych w jak najlepszych miejscach zapewniających wzrost wskaźników bibliometrycznych. Takie podejście ma uchronić naukowca przed konsekwencjami tego, co głosi słynne hasło „publish or perish” (Nabout et al. 2014), czyli przed wypadnięciem ze świata akademii.

System rozliczalności akademickiej jest nieustannie rozbudowywany i - zdaniem jego konstruktorów oraz wielu osób zarządzających nauką - ma służyć zwiększaniu jakości i doskonałości naukowej (Chowdhury, Koya i Philipson 2016): mają być osiągane coraz lepsze wyniki i wydawane coraz lepsze publikacje w coraz lepszych czasopismach. A przybliżeniem poziomu jakości tych czasopism ma być wskaźnik Impact Factor. System taki służy jednak także zwiększaniu kontroli nad naukowcami, ich sterowalności oraz ukierunkowaniu działań na cele pożądane z perspektywy polityki naukowej.

Budowa systemów rozliczalności oraz motywowania dla najlepszych (akademicka „grupa wyższa”) pozostawia w tych systemach szarą strefę dla „grupy średniej” i „grupy niższej” - tych, którzy nie są w stanie (,grupa średnia”) publikować w najlepszych miejscach i osiągać wysokich wskaźników bibliometrycznych, lub tych, którzy po prostu nic nie robią, ale system nie potrafi się ich pozbyć („grupa niższa”). Z perspektywy polityki naukowej wszyscy jednak muszą funkcjonować w tym samym systemie oceniania aktywności naukowej na podstawie jakości i poziomu produktywności naukowej.

Okazuje się jednak, że utrzymanie zakładanych celów systemu, czyli skutecznej i obiektywnej rozliczalności przy jednoczesnym zwiększaniu doskonałości naukowej, jest ograniczone ze względu na konieczność utrzymania w systemie wszystkich „grup” pracowników naukowych. Oznacza to, że przy zachowaniu minimalnego poziomu skutecznej i obiektywnej rozliczalności ma być możliwe funkcjonowanie wszystkich grup naukowców w systemie. 
Celem niniejszego artykułu jest zdefiniowanie i omówienie punktozy jako strategii naukowców służącej do jak najlepszego grania w grę parametryczną w Polsce. Definiując punktozę, pokażę na przykładzie polskiego systemu instytucjonalnej ewaluacji nauki, jakie mechanizmy ją wytwarzają oraz jak jej rozpowszechnienie wpływa na praktyki wydawnicze i publikacyjne.

Struktura niniejszego tekstu jest następująca: w drugiej części tekstu wskażę podstawowe cechy definicyjne punktozy, następnie skupiając się na systemie parametrycznym, opiszę mechanizmy zabezpieczające przed punktozą oraz takie, które ją wywołują. W ostatniej części, zadając pytanie o nieuniknioność punktozy, podsumuję zaprezentowane rozważania.

\section{Definicja punktozy}

Grą nazywam takie prowadzenie badań i publikowanie ich wyników (np. wybieranie „publikowalnych” problemów badawczych), które pozwala wpisywać się w priorytety i reguły funkcjonującego $\mathrm{w}$ danej społeczności akademickiej systemu ewaluacji nauki, jakiemu podlega dana społeczność akademicka. Może to być zarówno system krajowy, jak i lokalny system jednej uczelni czy wydziału. Granie w grę oznacza więc funkcjonowanie w społeczności akademickiej, awansowanie, zdobywanie stanowisk poprzez odpowiednie realizowanie celów systemu ewaluacji nauki.

W niniejszym tekście skupiam się na jednym z rodzajów gry, tj. grze parametrycznej, czyli takiej, która wynika z systemu oceny nauki opartego głównie na ilościowym podejściu do produktywności naukowców, zbudowanym na różnych wskaźnikach i parametrach. Gra parametryczna może być rozumiana jako rodzaj „gry wskaźników” (indicator game), o której piszą Roland Bal (2017), Maximilian Fochler i Sarah de Rijcke (2017) oraz Alan Irwin (2017). Gra wskaźników jest jednak pojęciem pojemniejszym i nieodnoszącym się jedynie do krajowych systemów ewaluacji nauki. $\mathrm{Z}$ uwagi na to, że interesuje mnie perspektywa bieżącego doskonalenia systemu ewaluacji nauki na peryferiach, w której dotychczas funkcjonowała parametryczna ocena z całym dobrodziejstwem inwentarza, wyłączam ze swoich rozważań zagadnienie makrostruktur. „Granie” i „ogrywanie” może się odbywać odmiennie w systemach, które są uznawane za „centrum” lub „peryferie” nauki (Warczok i Zarycki 2016). Można byłoby powiedzieć, że gra parametryczna jest inaczej „rozgrywana” w krajach o dominującej i uprzywilejowanej pozycji w nauce (np. Wielka Brytania czy Holandia), a inaczej w krajach o pozycji niższej (peryferyjnej) i aspirującej (Polska czy Czechy). W niniejszym tekście interesuje mnie wpływanie parametrycznego systemu ewaluacji na praktyki naukowców i w tym celu sięgam do polskiego przypadku. Mam jednak świadomość, że dodatkowy poziom interpretacyjny można byłoby uzyskać, biorąc pod uwagę odmienne ustrukturowanie pól akademickich (a zatem i zasad podejmowanych w nich gier). 
Używam kategorii „gry”, gdyż twórcy systemu ewaluacji nauki, implementując mechanizmy służące przeciwdziałaniu ogrywania systemu (np. ewaluatorzy stosują mechanizmy walidujące, czy jednostka nie wprowadza wielokrotnie jednej i tej samej publikacji z wysoko punktowanego czasopisma, jedynie nieznacznie zmieniając jej tytul), pokazują, że zdają sobie sprawę, iż naukowcy grają w „grę" Grą parametryczną jest zatem branie udziału w ocenie parametrycznej, a nie cała działalność naukowa uczonego czy też wszystkie badania. Do kategorii owej gry zaliczam tylko te badania i sposoby publikowania wyników, których celem jest przede wszystkim granie w grę.

W zależności od tego, czy dany system ewaluacji nauki jest nastawiony na ocenę poprzez ewaluację poziomu produktywności naukowca, czy ocenę jedynie jego najlepszych efektów publikacyjnych, można wyróżnić co najmniej dwie strategie prowadzenia i publikowania badań: impaktozę i punktozę.

Impaktoza została scharakteryzowana w kilku tekstach (Elsaie i Kammer 2009; van Diest, Holzel, Burnett i Crocker 2001) i zdefiniowana jako publikowanie wyników badań tylko w czasopismach, i to takich, które mają najwyższą wartość wskaźnika Impact Factor uznawanego w tym podejściu za bezpośrednią miarę jakości nie tylko czasopisma, ale również pośrednio opublikowanego w nim artykułu oraz autora tekstu. $\mathrm{W}$ tym podejściu inne publikacje w zasadzie się nie liczą. O oczekiwanych publikacjach można zatem powiedzieć: „im wyższy mają Impact Factor, tym lepiej".

Punktoza to podejście, którego definicję i charakterystykę proponuję w niniejszym tekście. W tym podejściu publikacja w najlepszym czasopiśmie może być zastąpiona kilkoma publikacjami w dużo gorszych czasopismach. W związku z tym punktoza sprawia, że w świetle reguł systemu ewaluacji nauki, który ją - co warto podkreślić - nieintencjonalnie wytwarza, opłaca się publikować dużo w kiepskiej jakości czasopismach i u nienajlepszych wydawców. W ostatecznym rozrachunku wynik jest taki sam: nieważne, czy mamy trzy publikacje w najbardziej prestiżowych czasopismach, czy trzydzieści publikacji w lokalnych, podrzędnych czasopismach. O oczekiwanych publikacjach w tym podejściu można zatem powiedzieć: „im ich więcej, tym lepiej”.

Obie strategie są - zgodnie z prawem Campbella (1979) - konsekwencją wykorzystania ilościowego wskaźnika (np. Impact Factora lub punktów za publikacje) do procesu podejmowania decyzji (pozytywna ocena w procesie awansowym). Campbell pokazywał, że każdy nadmiernie wykorzystywany wskaźniki poddawany jest presji korupcyjnej, przez co zaczyna wypaczać procesy, które miał jedynie mo-

${ }^{1}$ Mimo istotności zjawiska, w Polsce nie toczy się rzetelna naukowa dyskusja na ten temat. Poza nielicznymi głosami (Brzeziński 2016; Towpik 2017; Wróblewski 2017) trzon debaty stanowią teksty o charakterze publicystycznym, publikowane w organach prasowych środowiska akademickiego i na łamach uczelnianych czasopism. Przebieg tej debaty wyczerpująco przedstawiają Ostrowicka i Stasiak (2017). 
nitorować. $\mathrm{W}$ ten sposób miara staje się celem i robione jest to, co jest mierzone (ang. what gets measured gets done), a mierzone to, co się opłaca z perspektywy polityki naukowej (ang. whoever has the gold makes the rules). Dodatkowym problem jest jednak to - jak pokazują Łukasz Afeltowicz i Radosław Sojak (2015) w swojej krytyce parametrycznej oceny nauki - że mierząc naukę, dostajemy dokładnie to, co mierzymy (np. Impact Factory lub punkty ministerialne). Z czasem pewne praktyki zanikają i dochodzi do atrofii - jeśli jakiejś aktywności naukowej nie mierzymy, to ona po prostu przestaje się opłacać i naukowcy jej nie realizują. Jest to ogromne wyzwanie przede wszystkim dla konstruktorów wszelkich systemów ewaluacyjnych.

Impaktoza i punktoza są do siebie bardzo zbliżone, obie odnoszą się bowiem do zjawiska dostosowywania przez naukowców swoich praktyk publikacyjnych do ilościowo wyrażonej normy dotyczącej jakości. Można byłoby nawet powiedzieć, że impaktoza i punktoza są tym samym, gdyż „impakty” można zamienić na „punkty”. Jednak podstawową różnicą jest to, że w ramach impaktozy nie chodzi o „sumowanie impaktów" (w Polsce mówi się wręcz - w wytycznych dotyczących stopnia doktora habilitowanego - o sumarycznym Impact Factorze) z jakichkolwiek czasopism, lecz publikowanie tylko w tych najważniejszych z ważnych. Takie podejście kilka lat temu skrytykował Randy Scheckman, laureat Nagrody Nobla w dziedzinie fizjologii lub medycyny, pisząc wprost, że czasopisma Nature, Cell i Science niszczą naukę przez to, że wszyscy chcą publikować tam i tylko tam: bo tylko to daje uznanie i prestiż (Schekman 2013).

Natomiast punktoza, w odróżnieniu od impaktozy, to takie definiowanie celów badawczych, aby ich wyniki były publikowalne bez znaczącego wysiłku ze strony naukowca. Jedną z głównych przyczyn punktozy jest funkcjonowanie (najczęściej parametrycznego) systemu ewaluacji nauki w danej społeczności akademickiej oraz deinstytucjonalizacja misji badawczej uczelni. Chodzi zatem o: 1) zasady ewaluacji nauki przyjęte przez daną społeczność akademicką w oparciu o obowiązujący krajowy system (Kulczycki 2017) i 2) nadmierne ukierunkowanie uczelni i ich pracowników na kształcenie, przy jednoczesnym osłabieniu orientacji badawczej (Kwiek 2015). System oceny nauki wytwarza punktozę poprzez niektóre ze swoich mechanizmów (np. mechanizm dzielenia punktów za publikacje współautorskie), pozwalając $\mathrm{w}$ ten sposób na granie $\mathrm{w}$ grę parametryczną poprzez publikowanie wielu kiepskich publikacji. Takie publikacje są legitymizowane przez sam system, gdyż np. są publikowane w czasopismach uznawanych za naukowe w świetle reguł tego systemu (np. czasopisma te są uwzględniane w tworzonym lub uznawanym w danym systemie rankingu czasopism). Punktoza jest syndromem „chorej nauki”, w której nie prowadzi się badań, ale trzeba publikować „cokolwiek”, gdyż na podstawie publikacji pracownik jest rozliczany. W związku z tym można byłoby powiedzieć, że punktoza nie tyle zakłada definiowanie odpowiednich celów badawczych, ile po prostu jest strategią przetrwania w akademii poprzez symulowanie badań. 


\section{Zabezpieczenie i wytwarzanie - punktoza na przykładzie Kompleksowej Ewaluacji Jednostek Naukowych w Polsce}

Systemy oceny nauki o zasięgu krajowym mają największy wpływ na praktyki naukowe (Aagaard 2015; Aagaard i Schneider 2015; Rijcke i in. 2016). Są to najczęściej główne składniki systemów finansowania nauki opartych na efektach (ang. performance-based research funding systems). Ocena nauki odbywa się na poziomie instytucjonalnym (uczelnie, wydziały, całe dyscypliny), a nie na poziomie pojedynczego naukowca - chociaż oczywiście ostatecznie i tak mowa jest o dorobku i publikacjach poszczególnych pracowników.

Wśród obecnie funkcjonujących systemów można wskazać dwa główne rodzaje: 1) system oparty na ocenie eksperckiej (Chowdhury i in. 2016) - jego przykładem jest model brytyjski, czyli Research Excellence Framework; 2) system oparty głównie na ocenie parametrycznej - jednym z pierwszym krajów wdrażających ten model była Polska, a obecnie funkcjonuje on m.in. w Australii, Czechach, Danii, Flandrii i Norwegii (Kulczycki 2017).

Każdy z tych rodzajów systemów ma swoje wady i zalety. W niniejszym tekście skupiam się na problemach związanych z obecnie funkcjonującym polskim systemem parametrycznym.

\subsection{Mechanizmy zabezpieczające przed punktozą}

Poniżej scharakteryzuję dwa główne mechanizmy zabezpieczające przed punktozą wdrożone w systemie instytucjonalnej oceny nauki w Polsce, czyli rozwiązania ograniczające efekty podejścia „im więcej, tym lepiej”.

Ograniczenie liczby publikacji zgłaszanych przez jednostkę do oceny - jednostka naukowa może zgłosić do oceny za okres czterech lat maksymalnie tyle publikacji, ile wynosi (w uproszczeniu) trzykrotność liczby jej pracowników. Określane jest to formułą $3 \mathrm{~N}$, gdzie $\mathrm{N}$ to liczba pracowników danej jednostki. Regułę tę można przełożyć na wytyczną wskazującą pożądaną praktykę publikacyjną: w ciągu czterech lat opublikuj trzy bardzo dobre publikacje - więcej i tak nie będzie mogło zostać zgłoszonych. Oczywiście mechanizm ten działa tylko wówczas, gdy: 1) wszyscy pracownicy w jednostce publikują; 2) taka reguła jest „przekładana” na system oceny indywidualnego naukowca w poszczególnych jednostkach naukowych. Siła oddziaływania tego mechanizmu jest osłabiona, gdyż chociaż suma publikacji nie może przekroczyć $3 \mathrm{~N}$, to można zgłosić dowolną liczbę publikacji jednego pracownika (tych publikujących najwięcej i najlepiej określa się często mianem „kominów”, których publikacje wypełniają „lukę” po tych niepublikujących). 
Ograniczenie liczby monografii i rozdziałów zgłaszanych do oceny - w ramach $3 \mathrm{~N}$ publikacji jednostka może zgłosić ograniczoną liczbę monografii i rozdziałów. Najwięcej mogą zgłaszać jednostki naukowe z obszaru nauk humanistycznych i społecznych, gdzie 40\% wszystkich publikacji mogą stanowić monografie. Ograniczenie to zostało wprowadzone, aby - przy stosunkowo wysokiej liczbie punktów za monografie - uniemożliwić „drukowanie w garażu” książek quasi-naukowych i zgłaszanie ich w systemie ewaluacji jednostek naukowych. Mechanizm ten ma przyczyny w sposobie uznawania monografii, który definiuje monografie według kryteriów formalnych. Spełnienie warunków formalnych jest bardzo proste, zatem mechanizm ten ma być zabezpieczeniem przed taką praktyką „drukowania” monografii. Jednocześnie mechanizm ten wskazuje najbardziej pożądany (z perspektywy systemu) kanał komunikacji naukowej, czyli publikacje w czasopismach naukowych. Nie są one limitowane analogiczną formułą i można za nie otrzymać wyższą liczbę punktów. Jednakże uznawanie artykułów z czasopism nie opiera się na definicji formalnej, jak w przypadku monografii, lecz na tworzonym „Wykazie czasopism punktowanych”.

\subsection{Mechanizmy wytwarzające punktozę}

Mechanizmy wytwarzające punktozę nie są zaprojektowanym elementem systemu oceny nauki. Są konsekwencją konstrukcji jego poszczególnych elementów (np. punktoza wynikająca z zasad budowy Wykazu czasopism punktowanych), a swoje źródło mają w szerszych procesach społecznych, takich jak brak zaufania do ekspertów (Jabłecka i Lepori 2009) czy deinstytucjonalizacja misji badawczej (Kwiek 2015). W zasadach Kompleksowej Ewaluacji Jednostek Naukowych (Kulczycki 2017) z 2013 r. można wyróżnić pięć głównych mechanizmów wytwarzania punktozy.

Definiowanie monografii poprzez kryteria formalne - ocena książek oraz rozdziałów może odbywać się w systemach parametrycznych na dwa sposoby: 1) na podstawie listy uznanych wydawnictw naukowych (np. w Finlandii istnieje lista wydawców, tj. Julkaisufoorumi²) i tylko książki z uznanych wydawnictw są punktowane w ramach tzw. zasady „dziedziczenia prestiżu”, 2) według kryteriów formalnych, które musi spełnić dana książka (np. w Polsce jednym z podstawowych kryteriów jest objętość książki, wyrażona w arkuszach wydawniczych). Pierwszy sposób sprawia, że autorom - wedle reguł systemu - opłaca się publikować jedy-

${ }^{2}$ Listę kanałów publikacji (czasopism/wydawców) tworzą 23 panele eksperckie (łącznie ok. 200 naukowców) koordynowane przez Federację Fińskich Towarzystw Naukowych (Giménez-Toledo, Mañana-Rodríguez i Sivertsen 2017). W fińskim modelu wydawcy są klasyfikowani na czterech poziomach (w nawiasie kwadratowym podaję liczbę wydawców książek naukowych zaklasyfikowanych w ostatniej edycji listy): 1) top [15], 2) wiodący [93], 3) podstawowy [1159], 4) niezaakceptowany do poziomu podstawowego [1301]. 
nie w uznanych wydawnictwach, a wydawnictwom opłaca się utrzymywać poziom wydawniczy, aby nie wypaść z listy. Drugi sposób sprawia natomiast, że każde wydawnictwo, zakład produkujący pieczątki czy punkt ksero może wydawać książki i wszystkie te książki będą punktowane w ramach polskiego sytemu ewaluacji nauki. Opisane ograniczenie, polegające na redukowaniu np. do 40\% liczby monografii i rozdziałów zgłaszanych do oceny, nie spełni swojej roli, jeśli wszystkie te monografie zostaną wydane w podrzędnych wydawnictwach.

Podział punktów za publikacje wieloautorskie - to jeden z mechanizmów, którego konsekwencje są szczególnie istotne dla współpracy wewnątrzkrajowej lub zagranicznej. Podane przykłady systemów parametrycznych z innych krajów pokazują, że samo manipulowanie tym mechanizmem (np. przejście z podziału ułamkowego na całościowy) może przynieść istotne korzyści we współpracy lub spowodować jej ograniczenie (Schneider, Aagaard i Bloch 2014). Polski mechanizm podziału punktów za publikacje łączy dwa podejścia: podobnie jak w Norwegii podziału całościowego na poziomie jednostki naukowej oraz podziału całościowego stosowanego w systemie flamandzkim czy szwedzkim. Oznacza to, że dana publikacja nie jest liczona wielokrotnie w jednej jednostce, lecz - z perspektywy krajowego systemu - może być liczona wielokrotnie w różnych jednostkach. To natomiast sprawia, że badaczom opłaca się publikować przede wszystkim z autorami spoza własnej jednostki. Jednocześnie przy takim podziale punktów oraz zasadach uznawania monografii najbardziej opłaca się publikować w podrzędnych wydawnictwach wieloautorskie monografie (lecz nie prace pod redakcją!). Oczywiście autorzy pochodzą wówczas z różnych jednostek naukowych. I takie też zachęty do publikacji od quasi-wydawnictw pojawiają się już powszechnie w polskim środowisku naukowym. Mechanizm ten w połączeniu z formalnym definiowaniem monografii skutkuje pojawieniem się w Polsce tzw. drapieżnych konferencji i quasi-wydawnictw naukowych. Konferencje, skierowane głównie do młodych naukowców, których tematyka najczęściej zawiera się w sformułowaniu „od Sasa do Lasa”, kuszą np. tak: „Opublikujesz dwa recenzowane artykuły (ISBN, 5 punktów) oraz abstract [sic!] wystąpienia (ISBN), wygłosisz referat lub/i zaprezentujesz poster!"3. Jednocześnie organizatorzy dbają, aby podział punktów był jak najbardziej korzystny: „rozdziały do monografii naukowej mogą mieć maksymalnie 3 autorów. Istnieje możliwość odstępstwa od ograniczenia maksymalnej liczby autorów, jednak po [...] uzyskaniu jednoznacznej aprobaty ze strony Komitetu Organizacyjnego"4. Jednocześnie istnieje coś na kształt giełdy, na której można znaleźć miejsce w monografii, aby uzyskać punkty: „Nabór rozdziałów: monografie naukowe 25 pkt MNiSW za autorstwo rozdziału w monografii” ${ }^{5}$ - i tutaj oczywiście taką monografię wspól-

\footnotetext{
3 http://www.mlodzinaukowcy.com/Konferencja,392.html [25.10.2016].

${ }^{4} \mathrm{http}: / /$ www.konferencja-tygiel.pl/warsztaty/ [25.10.2016].

${ }^{5} \mathrm{http} / / /$ exante.com.pl/monografie-wieloautorskie-nabor-rozdzialow/ [25.10.2016].
} 
ną mogą pisać maksymalnie trzy osoby, aby uzyskać „pełnię punktów”. Taka przyjemność kosztuje jedynie 960 zł netto + 23\% VAT (od autora).

Brak zaufania do ekspertów skutkujący wiarą w obiektywność wskaźników - chociaż w polskim systemie (głównie) parametrycznym mamy również element oceny jakościowej (tzw. Kryterium IV), to jest on zarazem najczęściej krytykowanym składnikiem. Transformacje społeczne i polityczne po $1989 \mathrm{r}$. pociągnęły za sobą istotny spadek zaufania do ekspertów (Jabłecka i Lepori 2009). Podobną sytuację można zaobserwować w Czechach, gdzie stosowanie wskaźników parametrycznych zamiast ocen eksperckich było powodowane pragnieniem „depolityzacji i depersonalizacji procesów oceny i finansowania" (Good, Vermeulen, Tiefenthaler i Arnold 2015: 102). Warto również podkreślić, że w wielu dyscyplinach naukowych w Polsce środowisko akademickie jest zbyt małe, aby wdrożyć bez otwarcia się na zagranicznych ekspertów - dobre praktyki i rozwiązania w zakresie systemu eksperckiego (Łomnicki 1997). Ten brak wiary w ekspertów staje się mechanizmem legitymizującym jak najbardziej parametryczny system oceny, który jest wówczas postrzegany jako obiektywny, czyli niezależny od ekspertów, ich zainteresowań bądź woli politycznej. To natomiast sprawia, że system parametrów rozbudowywany ponad wszelkie granice rozsądku pozwala na uwzględnianie wszelkich przejawów działalności pracowników naukowych - doskonałość naukowa owych przejawów nie ma znaczenia, liczy się jedynie to, że w systemie istnieją parametry pozwalające uwzględnić i zmierzyć owe przejawy.

Wykaz czasopism punktowanych i zachęcanie do zakładania nowych czasopism - jednym z podstawowym mechanizmów polskiego systemu jest publikowany niemal corocznie „Wykaz czasopism punktowanych”. Jest to wykaz czasopism z przyporządkowanymi do nich punktami - opublikowanie artykułu przez pracownika jednostki w czasopiśmie z tego wykazu przynosi jednostce odpowiednią liczbę punktów. Mamy tu zatem podobną sytuację do wspomnianej fińskiej listy książkowych wydawnictw naukowych. Jednakże w polskim wykazie mogą znaleźć się czasopisma, które spełniają jedynie kryteria formalne - a w rzeczywistości tych kryteriów nie muszą spełniać, wystarczy jedynie deklarowanie ich spełniania. Wprowadzanie nowego czasopisma do wykazu jest często celem wielu pracowników naukowych i osób zarządzających jednostkami. Oczywiście samo wydawanie dobrego czasopisma jest bardzo potrzebne. Niestety zbyt często tworzy się w ten sposób miejsce do publikowania artykułów głównie przez własnych pracowników, co jest sprzeczne z samą ideą czasopisma naukowego. Warto jednak zaznaczyć, że zasady kategoryzacji jednostek naukowych dostarczały istotnej motywacji do zakładania nowych czasopism oraz wprowadzania ich na część A lub C „Wykazu”. Na początku systemu parametrycznego (tj. po 1999 r.), kiedy pracownik jednostki był redaktorem czasopisma indeksowanego w wykazie, jednostka otrzymywała za to punkty. Wraz z licznymi zmianami samego systemu rozwiązanie to było modyfikowane, aby ostatecznie punktowane było tylko bycie redaktorem czasopisma 
z części A wykazu (czasopisma z Impact Factorem). Efektem takiego kształtu regulacji jest zakładanie i wydawanie wielu quasi-naukowych czasopism: w ciągu trzech ostatnich edycji do części B wykazu zostało „wprowadzonych” 573 nowych polskich czasopism. Jednocześnie warto podkreślić, że część czasopism naukowych podniosło swoje standardy i praktyki wydawnicze właśnie dlatego, że zostały wskazane pożądane praktyki oraz zachęty (tj. dodatkowe punkty) do ich wdrażania.

Uczelniane progi awansowe i rankingowe oparte na systemie instytucjonalnej oceny nauki - w polskim systemie awansów naukowych punkty ministerialne, czyli punkty przyznawane jednostkom za publikacje ich pracowników w procesie parametrycznej oceny ich działalności, nie są uwzględnione w żadnym akcie prawnym. Jednakże rektorzy, dziekani, dyrektorzy instytutów badawczych zaczęli „tłumaczyć” reguły gry parametrycznej na zasady przyznawania awansów ${ }^{6}$. W zarządzeniach rektorów czy dziekanów zaczęły pojawiać się sformulowania nie tylko o rekomendowanej, lecz niekiedy wręcz wymaganej liczbie punktów, które musi zebrać dany kandydat na stopień naukowy lub tytul, aby można było przeprowadzić postępowanie awansowe - może to być 150, 200 czy 250 punktów. Takie przykłady mnożą się w polskim środowisku naukowym. Jednocześnie wiele z tych jednostek wymagających określonej liczby punktów pozwala na uzbieranie przez kandydata tych 150 punktów przez artykuły jedno- czy dwupunktowe (w „Wykazie czasopism punktowanych” z 2016 r. są 82 takie czasopisma). Jest to zachęta do punktozy w czystej postaci. Jeśli dodamy do tego coraz powszechniejszą praktykę tworzenia na uczelniach rankingów naukowców, doktorantów i studentów na podstawie „punktów ministerialnych”, to trudno się dziwić, że punktoza zaczyna być legitymizowana przez samo środowisko naukowe - skoro młodym naukowcom pokazuje się, że tak właśnie „robi się” naukę.

\section{Czy w Polsce jesteśmy skazani na punktozę?}

Punktoza nie jest intencjonalnie tworzonym mechanizmem, lecz stanowi konsekwencję budowy i założeń systemu oceny nauki tworzonego i wdrażanego w odpowiednim środowisku. Punktozy można uniknąć, a raczej ją ograniczyć, na dwa

6 Dla przykładu: 1) Uniwersytet Rolniczy w Krakowie na swojej stronie publikuje „Wymagania” (http://ur.krakow.pl/zasoby/79/BRKNiWzG_2014_zasady.pdf, 3.05.2017), w których w odniesieniu do stopnia doktora habilitowanego jest wskazane: „wartość dorobku naukowego według punktacji MNiSW powinna wynosić co najmniej 250 pkt”; 2) Wojskowy Instytut Medyczny w załączniku nr 2 do uchwały nr 105/IV/2013 z dnia 17.04.2013 r. pt. „Tryb przeprowadzania postępowania habilitacyjnego w Wojskowym Instytucie Medycznym” w pkt 2.1. stanowi: „dorobek publikacyjny w czasopismach międzynarodowych lub krajowych określonych w wykazie ministra, o wartości minimum 150 punktów" (http://www.wim.mil.pl/images/Rada\%20Naukowa/Tryby/tryb\%2oprzeprowadzania\%2opost\%CApowania\%2ohabilitacyjnego\%20(2).pdf, 3.05.2017). 
sposoby. Nie gwarantuje to oczywiście niewytworzenia nowych niepożądanych strategii grania w parametryczną grę.

Pierwszym sposobem jest przejście na system ekspercki. Musimy sobie jednak zdawać sprawę, że wówczas - w przypadku Polski - będziemy mieli problem z liczbą dostępnych ekspertów, którzy mogliby się podjąć ewaluacji. Jednocześnie musimy mieć na uwadze, czy polskiego podatnika stać na inny model niż model parametryczny. Dla porównania: jedna edycja polskiej kategoryzacji jednostek naukowych w 2013 r. kosztowała $3 \mathrm{mln}$ zł (Zabel 2013), natomiast jedna edycja oceny eksperckiej w Wielkiej Brytanii w 2014 r. - 33 mln funtów: w tym 19 mln funtów na wynagrodzenia dla ekspertów (Stern 2016). Jeśli do tego dołożymy 212 mln funtów, czyli koszty - trudne do oszacowania, więc należy podchodzić z rezerwą do wyliczeń - związane z samą pracą naukowców przy zgłaszaniu dorobku, to widzimy, że przy takich nakładach na naukę w Polsce jesteśmy skazani na punktozę. A dokładniej: jesteśmy skazani na system parametryczny, co nie znaczy, że nie możemy ograniczyć jego niepożądanych negatywnych konsekwencji.

Drugim sposobem jest zmodyfikowanie obecnego systemu parametrycznego. Po pierwsze, trzeba na poziomie polityki naukowej jasno zdefiniować cel systemu oceny nauki - nie może być nim, tak jak teraz, sama dystrybucja funduszy. Obecne rozwiązanie ujednolicone dla wszystkich grup nauk oraz jego wypaczone zastosowania koncentrują się na mierzeniu produktywności, a nie ocenie doskonałości naukowej prowadzonych badań. System oceny nauki powinien być narzędziem wspomagającym osiąganie celów wskazanych przez politykę naukową, np. zwiększanie doskonałości w nauce, umiędzynarodowienie czy też awans polskich uczelni w prestiżowych rankingach. Nie wszystkie te cele da się łatwo zmierzyć - umiędzynarodowienie można zmierzyć np. liczbą naukowców z zagranicy pracujących w Polsce, ale już ocena doskonałości w nauce wymaga przyjęcia różnych wskaźników, które nie zawsze muszą być zaakceptowane przez środowisko naukowe. Tak samo awans w prestiżowych rankingach uniwersytetów nie może być celem samym w sobie - twórcy rankingów poprzez odpowiedni dobór kryteriów (i ich nagłą zmianę) mogę wywrócić funkcjonującą dotąd klasyfikację (np. opartą na innych wskaźnikach) do góry nogami. Jednak wszystkie te cele w obecnym systemie społeczno-gospodarczym są ze sobą powiązane, dlatego system parametryczny musi je uwzględniać. Rolą tego systemu powinno być również dostarczanie informacji dla polityki naukowej o osiągnięciach polskich uczelni i instytucji naukowych ze wszystkich dziedzin. Jednocześnie musi on uwzględniać i dopasowywać narzędzia ewaluacji do specyfiki różnych grup nauk - w tym celu może np. korzystać z krajowych baz osiągnięć i publikacji oraz wspomagać rozwój takich narzędzi, jak Polska Bibliografia Naukowa czy Polska Bibliografia Prawnicza.

Po drugie, należy osłabić mechanizmy wytwarzające punktozę i wzmocnić te, które jej zapobiegają. Można to uzyskać np. 1) przebudowując zasady budowy „Wy- 
kazu czasopism punktowanych" tak, aby indeksowane na nim były tylko najlepsze czasopisma, 2) tworząc na kształt fińskiej listy katalog uznanych wydawców naukowych, 3) modyfikując zasady podziału punktów za publikacje wieloautorskie (im wyżej punktowane publikacje, tym korzystniejszy jest podział punktów) - pamiętając przede wszystkim o tym, aby nie zniszczyć w ten sposób współpracy zagranicznej oraz specyfiki praktyk publikacyjnych w danej dyscyplinie naukowej.

Wskazane dwa sposoby ograniczenia niepożądanych efektów punktozy mogą być wprowadzone na poziomie samego tworzenia i wdrażania systemu oceny nauki. Warto jednak podkreślić, że to my, naukowcy, gramy w parametryczną grę, podejmując się pracy na uczelniach i w instytutach badawczych. Wybór strategii zależy również od nas.

\section{Podziękowania}

Chciałbym serdecznie podziękować Ewie Rozkosz, Krystianowi Szadkowskiemu, Marcie N. Wróblewskiej za inspirującą krytykę i komentarze do pierwszej wersji tekstu, która została zaprezentowana na konferencji Komitetu w Nauce PAN pt. „Etyczne i społeczne aspekty parametryzacji w nauce", 28-29 października 2016 r. w Warszawie. Chciałbym również podziękować wszystkim komentatorom w serwisie Academia.edu, którzy w styczniu 2017 r. w ramach sesji dyskutowali nad mocnymi i słabymi stronami tego tekstu.

\section{Literatura}

Aagaard, K. (2015). How incentives trickle down: Local use of a national bibliometric indicator system. Science and Public Policy. 42(5), 725-737. doi:10.1093/scipol/scu087.

Aagaard, K., Schneider, J.W. (2015). Research funding and national academic performance: Examination of a Danish success story. Science and Public Policy. 1-14. doi:10.1093/ scipol/scvo58.

Afeltowicz Ł., Sojak, R. (2015) Arystokraci i rzemieślnicy. Synergia stylów badawczych. Toruń: Wyd. Nauk. UMK.

Antonowicz, D., Brzeziński, J.M. (2015). W poszukiwaniu optymalnego modelu szkolnictwa wyższego: w poszukiwaniu optymalnego modelu szkolnictwa wyższego. W: M.S. Szczepański, K. Szafraniec, A. Śliz (red.). Szkolnictwo wyższe, uniwersytet, ksztatcenie akademickie o obliczu koniecznej zmiany: ekspertyza Komitetu Socjologii Polskiej Akademii Nauk (95-119). Warszawa: PAN.

Bal, R. (2017). Playing the Indicator Game: Reflections on Strategies to Position an STS Group in a Multi-disciplinary Environment. Engaging Science, Technology, and Society. 3: 41. doi: 10.17351/ests2017.111.

Brzeziński, J.M. (2016). Przeciwko depersonalizacji i nadmiernej standaryzacji procesu ewaluacji w nauce. Zagadnienia Naukoznawstwa. 1(52): 127-138.

Campbell, D.T. (1979). Assessing the Impact of Planned Social Change. Evaluation and Program Planning. 2: 67-90. 
Chowdhury, G., Koya, K., Philipson, P. (2016). Measuring the Impact of Research: Lessons from the UK's Research Excellence Framework 2014. Plos One. 11(6). e0156978. doi:10.1371/journal.pone.0156978.

Diest, P.J. van, Holzel, H., Burnett, D., Crocker, J. (2001). Impactitis: New cures for an old disease. Journal of Clinical Pathology. 54(11): 817-819. doi:10.1136/jcp.54.11.817.

Elsaie, M., Kammer, J. (2009). Impactitis: The impact factor myth syndrome. Indian Journal of Dermatology. 54(1), 83-86. doi:10.4103/0019-5154.48998.

Fochler, M., Rijcke, S. de (2017). Implicated in the Indicator Game? An experimental Debate. Ests. 1: 21-40. doi:10.17351/ests2017.108.

Giménez-Toledo, E., Mañana-Rodríguez, J., Sivertsen, G. (2017). Scholarly book publishing: Its information sources for evaluation in the social sciences and humanities. Research Evaluation. o(0): 1-11. doi: 10.1093/reseval/rvxo07.

Godin, B. (2009). The value of science: changing conceptions of scientific productivity, 1869 to circa 1970. Social Science Information. 48(4): 547-586. doi:10.1177/0539018409344475.

Good, B., Vermeulen, N., Tiefenthaler, B., Arnold, E. (2015). Counting quality? The Czech performance-based research funding system. Research Evaluation. 24(2): 91-105. doi: 10.1093/reseval/rvuo35.

Hicks, D. (2012). Performance-based university research funding systems. Research Policy. 41(2): 251-261. doi: 10.1016/j.respol.2011.09.007.

Hicks, D., Wouters, P., Waltman, L., Rijcke, S. de, Rafols, I. (2015). Bibliometrics: The Leiden Manifesto for research metrics. Nature. 520(7548): 429-431. doi:10.1038/520429a.

Irwin, A. (2017). If the Indicator Game is the Answer, Then What is the Question? Engaging Science, Technology, and Society. 3: 64. doi:10.17351/ests2017.110.

Jabłecka, J., Lepori, B. (2009). Between historical heritage and policy learning: The reform of public research funding systems in Poland, 1989-2007. Science and Public Policy. 36(9): 697-708. doi: 10.3152/030234209X475263.

Kulczycki, E. (2016). Rethinking Open Science: The Role of Communication. Analele Universitatii din Craiova, Seria Filosofie. 37(1): 81-97.

Kulczycki, E. (2017). Assessing Publications through a Bibliometric Indicator: The Case of Comprehensive Evaluation of Scientific Units in Poland. Research Evaluation. doi: 10.1093/reseval/rvw023.

Kwiek, M. (2014). Structural changes in the Polish higher education system (1990-2010): a synthetic view. European Journal of Higher Education. 4(3): 266-280. doi:10.1080/ 21568235.2014.905965.

Kwiek, M. (2015) Podzielony uniwersytet. Od deinstytucjonalizacji do reinstytucjonalizacji misji badawczej polskich uczelni. Nauka i Szkolnictwo Wyższe. 2(46): 41-74. doi: http://dx.doi.org/10.14746/nsw.2015.2.2.

Larivière, V., Haustein, S., Mongeon, P., Solla Price, D. de, Haustein, S., Tenopir, C. i in. (2015). The Oligopoly of Academic Publishers in the Digital Era. Plos One. 10(6): e0127502. doi: 10.1371/journal.pone.0127502.

Łomnicki, A. (1997). A Polish Perspective on Peer Review. W: M.S. Frankel, J. Cave (red.). Evaluating Science and Scientists (61-70). Budapest: Central European University Press.

Nabout, J.C., Parreira, M. R., Teresa, F. B., Carneiro, F. M., Cunha, H. F. da, Souza Ondei, L. de $\mathrm{i}$ in. (2014). Publish (in a group) or perish (alone): The trend from single- to multi- 
authorship in biological papers. Scientometrics. 102(1): 357-364. doi:10.1007/s11192014-1385-5.

Ostrowicka, H., Spychalska-Stasiak, J. (2017). Uodpowiedzialnianie akademii - formacje wiedzy i władza parametryzacji w dyskursie akademickim. Nauka i Szkolnictwo Wyższe. 1(49): 105-131. doi: 10.14746/nisw.2017.1.6.

Rijcke, S. de, Wouters, P.F., Rushforth, A.D., Franssen, T.P., Hammarfelt, B. (2016). Evaluation practices and effects of indicator use: A literature review. Research Evaluation. 25(2): 161-169. doi:10.1093/reseval/rvvo38.

Schekman, R. (2013). How journals like Nature, Cell and Science are damaging science. https://www.theguardian.com/commentisfree/2013/dec/09/how-journals-nature-science-cell-damage-science [16.01.2017].

Schneider, J.W., Aagaard, K., Bloch, C.W. (2014). What happens when funding is linked to (differentiated) publication counts? New insights from an evaluation of the Norwegian Publication Indicator. W: E. Noyons (red.). Proceedings of the science and technology indicators conference 2014 Leiden „Context Counts: Pathways to Master Big and Little Data” (543-550). Leiden: Universiteit Leiden.

Stern, N. (2016). Building on Success and Learning from Experience: An Independent Review of the Research Excellence Framework. Department for Business, Energy \& Industrial Strategy.

Szadkowski, K. (2015). Uniwersytet jako dobro wspólne. Podstawy krytycznych badań nad szkolnictwem wyższym. Warszawa: Wyd. Nauk. PWN.

Szadkowski, K. (2016). Socially Necessary Impact/Time: Notes on The Acceleration of Academic Labor, Metrics and The Transnational Association of Capitals. Teorie Vědy/ Theory of Science. 38(1): 53-85.

Towpik, E. (2015). IF-mania: Journal Impact Factor nie jest właściwym wskaźnikiem oceniania wyników badań naukowych, indywidualnych uczonych ani ośrodków badawczych. Nowotwory. Journal of Oncology. 65: 465-475.

Vostal, F. (2016). Accelerating Academia: The Changing Structure of Academic Time. Basingstoke: Palgrave Macmillan.

Warczok, T., Zarycki, T. (2016). Polska politologia $w$ globalnym polu nauk spolecznych. Warszawa: Scholar.

Wilsdon, J., Allen, L., Belfiore, E., Campbell, P., Curry, S., Hill, S. i in. (2015). The Metric Tide: Report of the Independent Review of the Role of Metrics in Research Assessment and Management. HEFCE. doi: 10.13140/RG.2.1.4929.1363.

Wróblewski, A. K. (2017). Nie wszystko, co się liczy, da się policzyć... Nauka. 1: 7-22.

Zabel, M. (2013). Gorączka ewaluacji. Forum Akademickie. 10: 30-35.

\section{Running for Points as a Strategy in the "Parametric Game" in Poland}

ABSTRACT. The paper uses the concept of 'parametric game' to describe a strategy of academic work which has become wide-spread in Poland, due to the introduction of a particular policy of rewards. The 'parametric game' consists of doing research and publishing results in so as to enable fulfill- 
ing the requirements of a given research evaluation system. On the whole, researchers can use two main strategies in this game. The first strategy is 'Impactitis,' where only publications in journals with a high Impact Factor are acknowledged by a given scholarly community. The other strategy, whose definition and understanding are put forward in the present paper, is the so-called 'running for points' (the original Polish term being 'punktoza'). In this strategy, the most 'profitable' choice is to publish several articles in journals without any Impact Factor rather than one paper in a toptier journal. On the basis of the Polish system, I present the main mechanisms that produce the running-for-points strategy and several mechanisms that make it possible to reduce the negative consequences of playing the parametric game in this way. The article concludes with a discussion of the Polish system. It suggests how the system can be improved and what lessons can be learnt from it. The conclusions are relevant for both scholars and policy makers in other countries.

KEYWORDS: parametric game, running for points, impactitis, Poland, research evaluation

CYTOWANIE: Kulczycki, E. (2017). Punktoza jako strategia w grze parametrycznej w Polsce. Nauka i Szkolnictwo Wyższe. 1(49): 63-78. doi: 10.14746/nisw.2017.1.4. 